\title{
Transition Curvature and Readback Pulse Width in Perpendicular Magnetic Recording
}

\author{
Y. Yamakawa, K. Miura, H. Muraoka, H. Aoi, and Y. Nakamura \\ Research Institute of Electrical Communication, Tohoku Univ., 2-1-1 Katahira, Aoba-ku, Sendai 980-8577, Japan
}

\begin{abstract}
In perpendicular magnetic recording, track edge noise, write fringing, and transition curvature are crucial issues that need to be addressed in order to increase track density. In particular, it is thought that the transition curvature at the written track edges broadens readback pulse width through the azimuth loss effect, but quantitative discussion of this phenomenon has not been sufficient. In this paper we extract transition lines observed in MFM images, and examine the influence of the transition curvature on the readback pulse width and transition jitter. Our findings show that this influence is not very large, and that deterioration of the writing resolution or broadening of the transition width at the track edges is more significant.
\end{abstract}

Key words: transition curvature, readback pulse width

\section{垂直磁気記録における磁化転移ライン湾曲と再生波形パルス幅}

\author{
山川慶之・三浦健司・村岡裕明・青井基・中村慶久 \\ 東北大学電気通信研究所, 宮城県仙台市青葉区片平 2-1-1（干980-8577）
}

1. はじめに

今後の垂直磁気記録における高面密度化にはトラック密度の向 上が重要な要件であり, $100 \mathrm{~nm}$ 以下の狭トラック幅の実現が緊急 の課題である. しかしこのような狭トラック垂直磁気記録にお いては記録再生にじみによるトラック幅の増大やトラック エッジノイズによる SN 比の劣化, 磁化転移のトラック端 部での湾曲 1)が懸念されている。この中で磁化転移ライン の湾曲はトラック端における等価的な分解能の劣化を引き 起こすことが推測されるが，湾曲と分解能劣化の関係は必 ずしも明らかになっていない。本報告では MFM 像から転 移ラインの形状を抽出し, 湾曲による再生波形のパルス幅 の広がりやトラック各部での記録分解能への影響などにつ いて検討を行った。

\section{2. 実験方法}

実験装置は記録再生測定にはスピンスタンドを用い，磁気像の 観察にはディジタルインスツルメンツ社製 MFM(Nanoscope III a)を用いた. 記録再生ヘッドにはマージ型の単磁極へッド $\left(\mathrm{T}_{\mathrm{ww}}\right.$ :

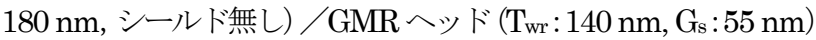
を用いた，媒体は $\mathrm{CoPtCr}-\mathrm{SiO}_{2}$ 垂直二層膜媒体を用い，その諸元 はTable 1 に示すとおりである. 初期状態はACバンドイレーズと して $1200 \mathrm{kFCI}$ を記録電流 $50 \mathrm{~mA}_{0 \text { p }}$ で書き込み, その後記録電流 30, 40, $50 \mathrm{~mA} 0$-p，記録密度 $100 \mathrm{kFCI}$ で記録を行った．時間軸解 析2)をもちいて転移ジッタ距離, бjitter を測定した.

Table 1 Specifications of a $\mathrm{CoPtCr}-\mathrm{SiO}_{2}$ double-layered perpendicular medium

\begin{tabular}{|c|c|c|c|c|}
\hline $\begin{array}{c}M_{\mathrm{s}} \\
\left(\mathrm{emu} / \mathrm{cm}^{3}\right)\end{array}$ & $M_{\mathrm{r}} / M_{\mathrm{s}}$ & $\begin{array}{c}H_{\mathrm{c}} \\
(\mathrm{kOe})\end{array}$ & $\begin{array}{c}H_{0} \\
(\mathrm{kOe})\end{array}$ & $K_{\mathrm{u}} V k T$ \\
\hline 646 & 0.83 & 3.5 & 8.3 & 81 \\
\hline
\end{tabular}

\section{3. 計算方法}

\section{1 磁化転移ラインの抽出方法}

MFM 像からできるだけ高精度に磁化転移ラインを抽出するた めに(1)式に示寸相互相関関数を用いた. Fig. 1 に示寸ように着目 したトラックを MFM 像のダウントラック方向スキャンごと(約 8 $\mathrm{nm}$ 間隔) のマイクロトラックの集合と見なし, そのうち中央付近 の 1 つを基淮マイクロトラック 磁化 $\left(f_{0}(k)\right)$ として他のマイクロ トラック 磁化 $\left(f_{\mathrm{z}}(k)\right)$ との相互相関関数 $R(l)$ を求めた. ただし $N$ は各マイクロトラックのデータ数である. 湾曲によって $f_{0}$ と $f_{\mathrm{z}}$ の 信号には図示するような位相差があり, この相互相関関数の最大 值の位置より基淮マイクロトラックとの位相差を求めた. これを クロストラック位置の関数で表現して磁化転移ラインを得た.

$$
R_{f_{0} f_{z}}(l)=\left\{\begin{array}{lc}
\frac{1}{N+l} \sum_{k=1}^{N+l} f_{0}(k) \cdot f_{z}(k-l) & \text { for } l=-N+1 \cdots-1 \\
\frac{1}{N-l} \sum_{k=1}^{N-l} f_{0}(l+k) \cdot f_{z}(l) & \text { for } l=0,1 \cdots N-1
\end{array}\right.
$$

$f_{\mathrm{z}}(k)$ を $f_{0}(k)$ に対して移動させながら積和計算をして, 相互相関演算 を行っており, $f_{0}$ と $f_{\mathrm{z}}$ のデータ点数が等しいので上式は $f_{\mathrm{z}}(k)$ が $f_{0}(k)$ より左にあるとき $(l<0)$ で, 下式は右にあるとき $(l \geqq 0)$ の計算式で ある.

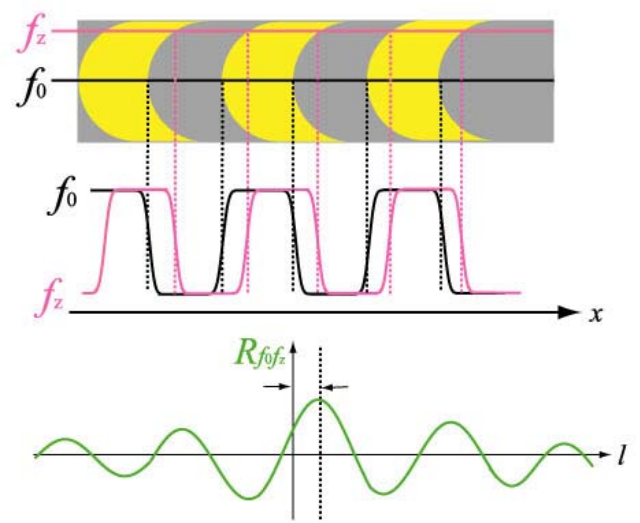

Fig. 1 Schematic diagram of a cross-correlation operation. 


\section{2 湾曲によるパルス幅の広がりの計算方法}

転移湾曲による再生波形パルス幅の広がりは，マイクロトラック 磁化転移を規格化誤差関数 $M_{0}(x)$ でモデル化したものと前述の方法 で抽出した転移ラインによる位相変動を用いて計算した。

$$
M_{0}(x)=\operatorname{erf}\left(\frac{x}{\sqrt{\pi} a}\right)
$$

まず転移形状に沿って実測值に合わせた磁化転移幅 $a$ を有する複 数の誤差関数を配置し，これを再生へッドのトラック幅で積分し 再生ヘッドの感度関数 3)を相反定理に従って畳多込多演算を行っ て再生波形を得た。これを再生へッドをトラック中央から片側に オフトラックさせた各位置について計算してパルス幅 $\mathrm{T}_{50}$ をプロ ットした.

\section{4. 実験結果}

\section{1 磁化転移ラインの抽出}

Fig. 2 に観察したトラックの MFM 像（上）とそこから抽出した 磁化転移ライン（下）を示す。ここで磁化転移ラインはヘッド走 行方向を横軸，クロストラック方向を縦軸にしている. 測定して 抽出した各記録電流で記録された全ての磁化転移ラインにトラッ ク端での湾曲が確認された. ここで磁化転移がヘッド磁化反転に よってトレーリング端に生じるものであるから減磁界の影響を無 視した第一近似としてはへッド磁界の等高線とこの磁化転移ライ ンが一致するはずである。これを定性的に比較するためへッド磁 界を 3 次元有限要素法で計算した. 更に, 斜め磁界印加による反 転磁界低減効果を考慮するために式(3) によって得た実効的な磁 界 $H_{\mathrm{eff}}$ の媒体厚夕方向の磁界分布を Fig. 3 に示寸.

$$
\begin{aligned}
& H_{\text {eff }}=\left(H_{1}^{2 / 3}+H_{y}^{2 / 3}\right)^{3 / 2} \\
& \left(H_{1}=\sqrt{H_{x}^{2}+H_{z}^{2}}\right)
\end{aligned}
$$

この磁界分布の形状はトラック中央からトラック端にかけて概ね $50 \mathrm{~nm}$ の湾曲に相当するが, 上述の MFM 観測值はこれに近く, 概ね妥当な範囲と考えられる. 特に大電流励磁の場合, 等磁界強 度線は外側に推移するので湾曲が強調される傾向が認められる.

ここで記録分解能を規定する磁界勾配の様子を知るため，一例 として磁界強度 $6 \mathrm{kOe}$ 付近のトラック中央とトラック端のヘッド 磁界勾配について計算した. 磁界勾配はトラック中央の約 120 $\mathrm{Oe} / \mathrm{nm}$ に対し，トラック中央から $130 \mathrm{~nm}$ オフトラックした位置 では 40〜60 Oe/nm と半分以下に低下した. このへッド磁界分布 からは, トラック端での記録分解能の劣化が示唆される.

\section{2 湾曲によるパルス幅の広がり}

Fig. 4 に計算により求めた再生パルス幅 $\mathrm{T}_{50}$ の再生へ ッドオフトラック位置依存性を示す。横軸の 0 がヘッドが トラック中央に位置する状態である。この計算方法では湾 曲が存在する場合, リードヘッドのトラック幅全てがオン トラックしている範囲ではへッドがオフトラックするほど 平均化する転移湾曲の位相差が大きくなりパルス幅 $\mathrm{T}_{50}$ は 増加することになる。一方, リードヘッドが記録トラック の外側にオフトラックすると, 再生ヘッドの全リード幅に よる平均ではなく, 記録トラック上にある部分だけのより 狭いリード幅での再生になるため湾曲が $\mathrm{T}_{50}$ に与える影響 は減少することになる。ここではオフトラック位置が 50 $\mathrm{nm}$ 付近が外れ始める位置で, $\mathrm{T}_{50}$ は増加から減少に変化し ている. 同図より湾曲のみによる $\mathrm{T}_{50}$ の劣化は湾曲が大き くても高々 $8 \mathrm{~nm}$ 程度である. しかし Fig. 5 に示す実測に おける $\mathrm{T}_{50}$ のへッドオフトラック位置依存性はヘッドがオ フトラックするほど増大している。 この 2 つの結果より転
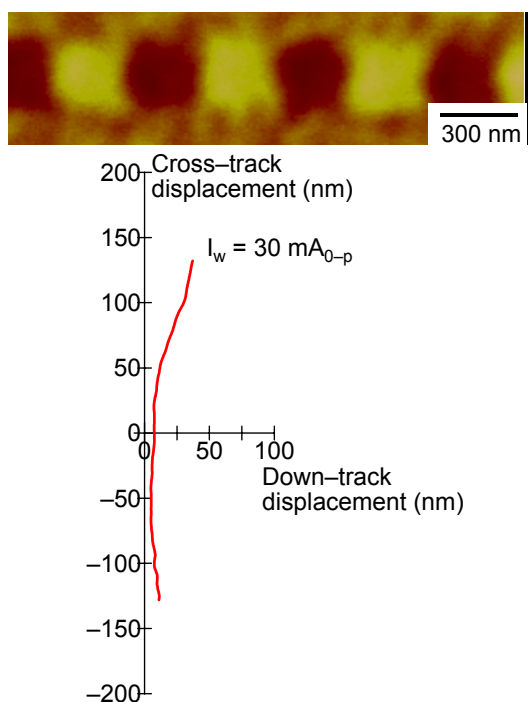

(a) $\mathrm{I}_{\mathrm{w}}: 30 \mathrm{~mA} 0 \mathrm{p}$
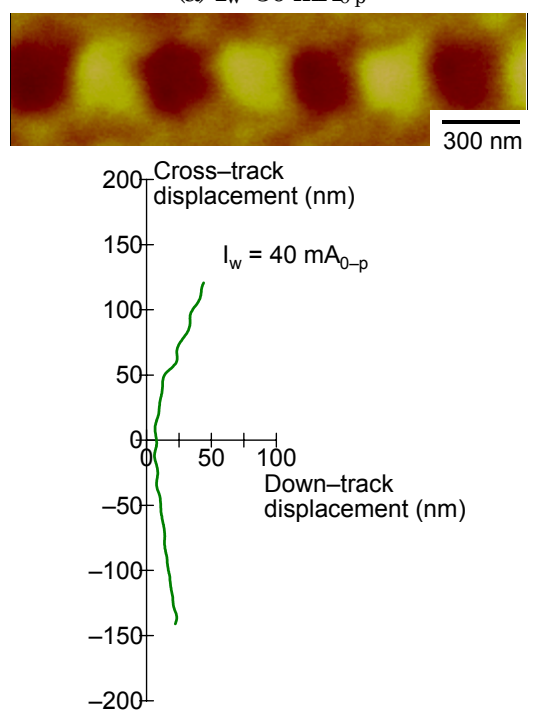

(b) $\mathrm{I}_{\mathrm{w}}: 40 \mathrm{~mA}_{0-\mathrm{p}}$

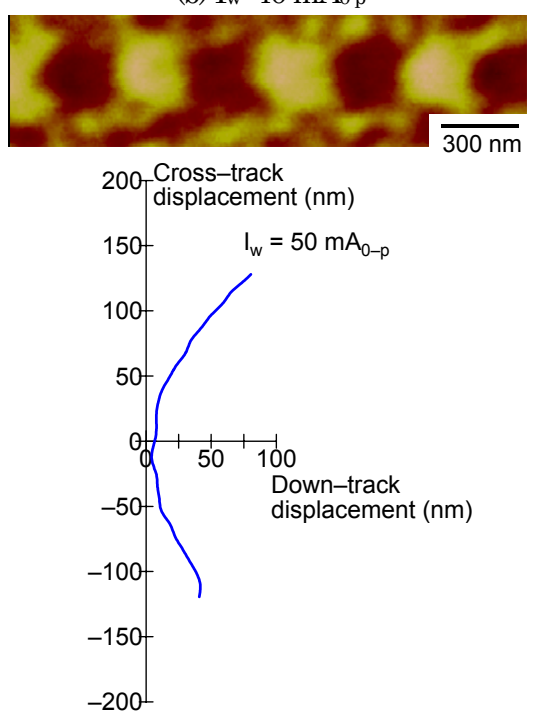

(c) $\mathrm{I}_{\mathrm{w}}: 50 \mathrm{~mA}_{0-\mathrm{p}}$

Fig. 2 MFM images of the tracks recorded at $100 \mathrm{kFCI}$ by changing the write current and transition lines extracted from the MFM images. 


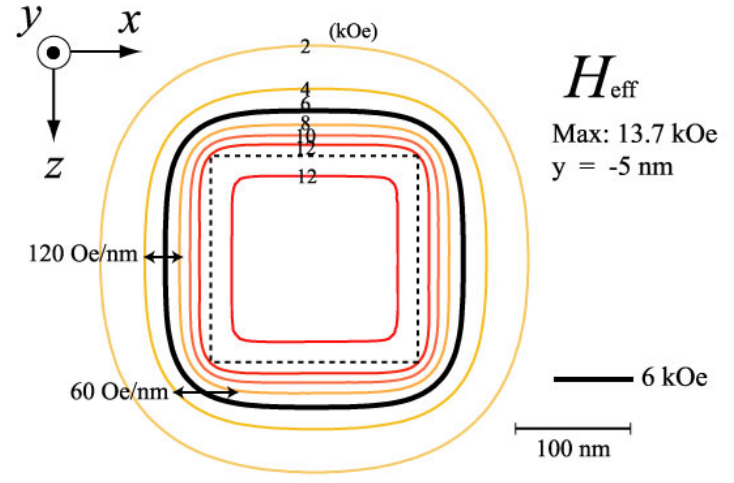

Fig. 3 Typical head field distribution calculated by $3 \mathrm{D}$ FEM simulation. $(\delta=10 \mathrm{~nm}, \mathrm{FH}: 10 \mathrm{~nm})$

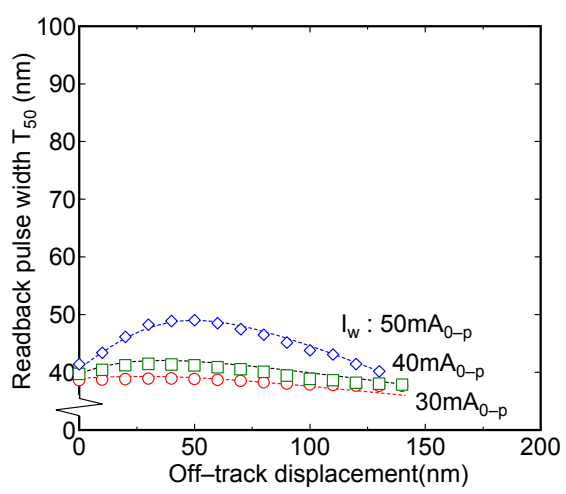

Fig. 4 Dependence of the readback pulse width $\mathrm{T}_{50}$ on the off-track displacement (calculation).

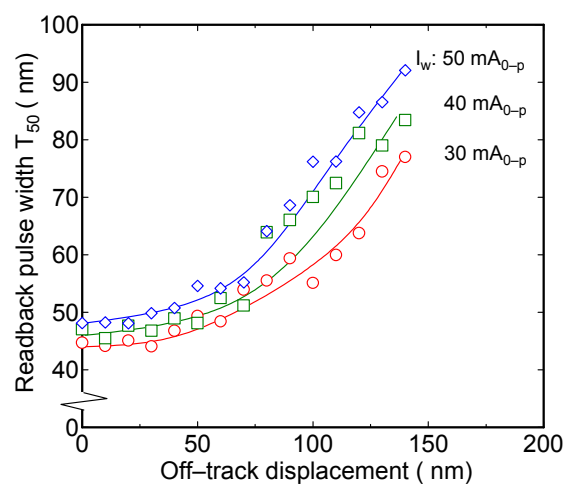

Fig. 5 Dependence of the readback pulse width $\mathrm{T}_{50}$ on the off-track displacement (experiment).

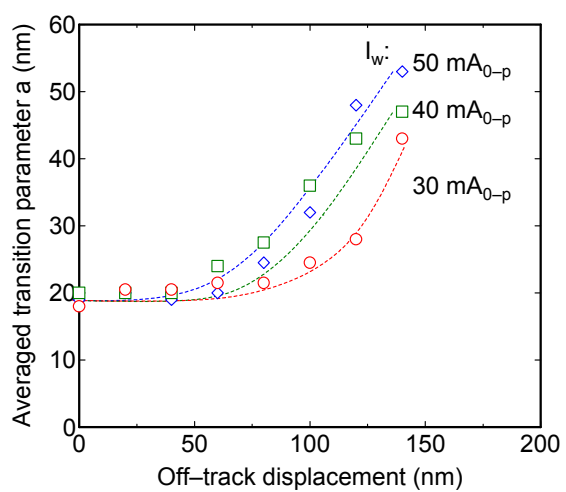

Fig. 6 Estimation of averaged transition parameter $a$.
移湾曲による影響だけでは実測の結果を説明できず，磁化 転移幅自体がトラック端で増大していることが推測される. そこで予め各々のオフトラック位置で再生パルス幅 $\mathrm{T}_{50}$ と転移パラメータ $a$ の対応について 3 次元ヘッド感度関数 による相反定理から計算しておき，実測值と比較して $\mathrm{T}_{50}$ が一致する $a$ の值を選び出してプロットした. その結果を Fig. 6 に示す. どの記録電流においてもトラック端で急激 に $a$ が大きくなる.ここでの $a$ はそれぞれのオフトラック 位置で再生ヘッドのトラック幅にわたって平均したもので マイクロトラックでの $a$ に対応するものではないが, トラッ ク端で記録分解能が劣化する明らかな傾向を示している.

\section{3 転移ジッタの再生ヘッドオフトラック位置依存性}

Fig. 7 に実測波形の時間軸解析より求めた転移ジッタの ヘッドオフトラック位置依存性を示す。どの記録電流にお いてもトラック端においてジッタが増大しており，記録電 流が大きいほどその傾向は顕著である。ここでリードトラ ック幅が減少すればジッタ量はその平方根の逆数に比例し て増加するから ${ }^{4)}$ ，オフトラックさせる測定ではこれを勘 案することが必要である。信号振幅のオフトラックプロフ アイルより実効的な記録幅 $\mathrm{T}_{\mathrm{ww}}$, 再生幅 $\mathrm{T}_{\mathrm{wr}}$ は, それぞれ約 $270 \mathrm{~nm}$, 約 $148 \mathrm{~nm}$ であった. これらに対してリードヘッ ドの位置によって記録トラック上に再生ヘッドがあって信 号を読み込むリード幅 $\mathrm{T}_{\text {read }}$ はオフトラック量 $z$ に応じて (4a)式のように場合分けして示される.また，このリード幅 の減少だけによるジッタの増加は(4b)式のように平方根に 依存する。

$$
\begin{aligned}
& T_{\text {read }}=\left\{\begin{array}{ccc}
T_{\mathrm{wr}} & \text { for } & z \leq \frac{T_{\mathrm{ww}}-T_{\mathrm{wr}}}{2} \\
\frac{T_{\mathrm{ww}}+T_{\mathrm{wr}}}{2}-z & \text { for } & z>\frac{T_{\mathrm{ww}}-T_{\mathrm{wr}}}{2}
\end{array}\right. \\
& \sigma_{\text {jitter comp }}=\sqrt{\frac{T_{\mathrm{read}}}{T_{\mathrm{wr}}}} \cdot \sigma_{\text {jitter exp }}
\end{aligned}
$$

この式を用いて実験のジッタ值 $\sigma_{\text {jitter exp }}$ を補正した $\sigma_{\text {jitter }}$ comp を compensated として同図中に示す. 実測ではトラッ ク端で更にジッタ量が大きくなっており，単にオフトラッ クによるリードトラック幅の減少では説明できない信号品 質の劣化を示唆している.

同様に各記録電流で記録されたトラックの MFM 像から 求めた転移ジッタの計算值を Fig. 8 に示す。上述の記録再 生特性の実測から得られたジッタ量に比べて值が大きいの は，MFM スキャン磁化転移ジッタを直接測定しており， トラック幅に相当する実効的な読み取り幅が Fig. 7 での磁 気ヘッドより狭いために転移摇らぎの平滑化効果が小さい ためである。なお，やはりトラック端においてジッタが増 大し記録電流が大きいほどその傾向は顕著である。これは シミュレーションの結果で述べたようにトラック端ほどダ ウントラック方向でのヘッド記録磁界勾配が緩やかになる ためであると考えられる。 


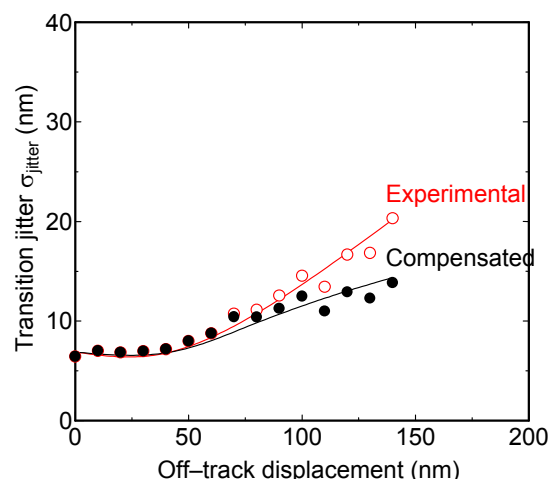

(a) $\mathrm{I}_{\mathrm{w}}: 30 \mathrm{~mA}_{0-\mathrm{p}}$

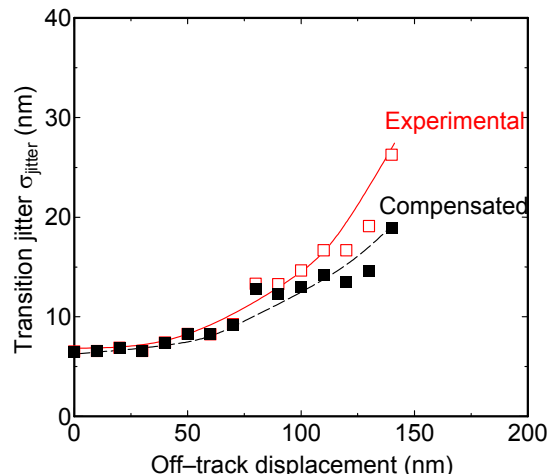

(b) $\mathrm{I}_{\mathrm{w}}: 40 \mathrm{~mA}_{0-\mathrm{p}}$

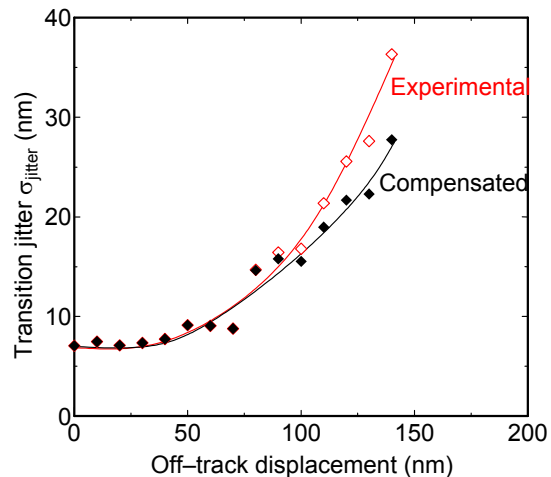

(c) $\mathrm{I}_{\mathrm{w}}: 50 \mathrm{~mA} 0-\mathrm{p}$

Fig. 7 Dependence of transition jitter $\sigma_{\text {jitter }}$ on the off-track displacement (experiment).

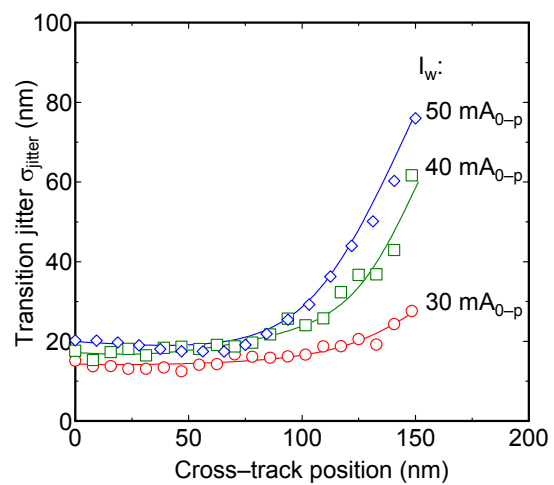

Fig. 8 Dependence of the transition jitter $\sigma_{\text {jitter }}$ on the off-track displacement (MFM).

\section{5. まとめ}

記録されたトラックの MFM 像より相互相関関数を用い ることで磁化転移ラインを抽出し, 湾曲による再生波形パ ルス幅の広がりを考察した。ここでは得られた転移ライン よりトラック上で転移幅が一定として算出した湾曲の影響 による影響は比較的小さいことが分かった．記録再生特性 の実測結果を説明するには湾曲だけではなくトラック端で の転移の広がりを考慮する必要があり, トラック端で転移 幅はトラック中央に比べ 2 倍以上にまで増加している可能 性が示唆された．転移ジッタ測定からもトラック中央にく らべトラック端では転移ジッタが大きく増大しており，記 録電流が大きいほどその傾向は顕著であった，以上より卜 ラック端において信号品質が劣化していることが示唆され た。これらトラック端での転移幅の広がりは記録へッドの 磁界勾配の低下が関与している可能性があり 5), 実際，3 次元有限要素法によるへッド磁界計算からもトラック端で は半分以下に勾配が劣化することが示された。

記録へッドのトラック端における磁界勾配が重要である ことを指摘した。すなわちトラックの外側では急峻に減衰 するとともに，その内側ではクロストラック方向に均一な 磁界分布を実現することであり，これによりトラック端の 転移幅の広がりとジッタの増大を抑制して高トラック密度 化できると考えられる.

謝辞 本研究の一部は, 文部科学省平成 14 年科学技術試験 研究, RR2002 (超小型大容量ハードディスクの開発), SRC の支援を得て行った。謝意を表する.

\section{References}

1) David J. Seagle, Matthew C. Barsotti, Marc L. Osborn, and Vincent M. Tobin: IEEE Trans. Magn., 35,619(1999).

2) K. Miura, H. Muraoka, Y. Sugita, and Y. Nakamura: J.Magn. Soc. Jpn., 24,231(2000).

3) H. Muraoka, Y. Sugita, and Y. Nakamura: IEEE Trans. Magn., 35, 2235(1999).

4) A. Moser, K. A. Rubin, and M. E. Best: IEEE Trans. Magn., 37, 1872(2001).

5) K. Miura, H. Muraoka, and Y. Nakamura: IEEE Trans. Magn., 37, 1926(2001).

2005 年 10 月 19 日受理, 2006 年 3 月 6 日採録 